\title{
THE CONTENT OF LEAD, CADMIUM, ARSENIC, MERCURY AND TIN IN FRUIT AND THEIR PRODUCTS BASED ON MONITORING STUDIES - EXPOSURE ASSESSMENT
}

\author{
Monika Manial, Małgorzata Rebeniak ${ }^{1}$, Ewelina Chabros ${ }^{1}$, Oksana Orshulyak $^{1}$, Jacek Postupolski $^{1}$
}

${ }^{1}$ National Institute of Public Health NIH - National Research Institute, Department of Food Safety, Warsaw, Poland

\begin{abstract}
Background. Fruit and fruit products are important part of our daily diet. In addition to the ingredients necessary for the proper functioning of the body, these products can also be a source of intake elements harmful to human health.

Objective. Analysis of the results of monitoring studies conducted in Poland in 2015 concerning contamination of lead $(\mathrm{Pb})$, cadmium $(\mathrm{Cd})$, arsenic $(\mathrm{As})$, mercury $(\mathrm{Hg})$ and tin $(\mathrm{Sn})$ in fruit and fruit products and exposure assessment.

Material and methods. Approximately 600 samples of fresh, frozen, dried fruits, fruit preserves and canned fruits were tested. The laboratories of State Sanitary Inspection were involved in testing. Accredited and validated analytical methods were used. The test samples were prepared in accordance with the standard PN-EN 13804:2013. The contents of lead, cadmium and tin were determined by using flame atomic absorption spectrometry (FAAS) or flameless with electrothermal atomization spectrometry (GFAAS); arsenic by using hydride generation atomic absorption spectrometry method (HGAAS) and mercury the "cold vapor" atomic absorption spectrometry (CVAAS) method.

Results. Contamination of investigated samples with elements harmful to human health ( $\mathrm{Pb}, \mathrm{Ca}, \mathrm{As}$, $\mathrm{Hg}$ and $\mathrm{Sn}$ does not rise concern to human health and was in most cases comparable with contamination reported in other European Union countries. The estimated average exposure of adults and children to lead intake with fruit and fruit products ranged from $0.5 \%$ to $14.6 \%$ of the respective Benchmark Dose Lower Confidence Limit (BMDL) established by the European Food Safety Authority (EFSA). The mean intake of cadmium with these groups of foodstuffs was in the range $0.3-8.5 \%$ of the TWI value (Tolerable Weekly Intake) established by EFSA for adults and children $(0.1-3.6 \%$ of the PTMI (Provisional Tolerable Monthly Intake) established by JECFA. In case of arsenic mean intake was in the range $0.5-1.6 \%$ BMDL whilst for mercury (inorganic form) intake represented $0.5-1.4 \%$ of TWI value established by JECFA and then confirmed by EFSA.

Conclusions. Based on the obtained results, it was found that content of $\mathrm{Pb}, \mathrm{Cd}, \mathrm{As}, \mathrm{Hg}$ and $\mathrm{Sn}$ in the tested samples of fruit and their products does not pose a risk to consumer health. Estimated exposure of consumers does not exceed tolerable doses established by EFSA and JECFA for these elements.
\end{abstract}

Key words: food, fruit, monitoring, lead, cadmium, mercury, arsenic, tin, exposure assessment

\section{STRESZCZENIE}

Wprowadzenie. Owoce i przetwory owocowe stanowią istotną część naszej codziennej diety. Poza składnikami niezbędnymi do prawidłowego funkcjonowania organizmu, produkty te mogą być również źródłem pobrania pierwiastków szkodliwych dla zdrowia.

Cel badań. Analiza wyników badań monitoringowych przeprowadzonych w Polsce w 2015 roku dotyczących zanieczyszczenia owoców i produktów owocowych pierwiastkami szkodliwymi dla zdrowia - ołowiem $(\mathrm{Pb})$, kadmem (Cd), arsenem (As), rtęcią (Hg) i cyną (Sn) oraz ocena narażenia.

Material i metody. Przebadano około 600 próbek świeżych, mrożonych i suszonych owoców, przetworów owocowych i owoców w puszkach. W badania zaangażowane były laboratoria Państwowej Inspekcji Sanitarnej. Zastosowano akredytowane i zwalidowane metody analityczne. Próbki do badań zostały przygotowane zgodnie z normą PN-EN 13804:2013. Zawartość ołowiu, kadmu i cyny oznaczono metodą płomieniową absorpcyjnej spektrometrii atomowej (FAAS) lub bezpłomieniową z atomizacją elektrotermiczną (GFAAS); arsen przy użyciu metody absorpcyjnej spektrometrii atomowej z generowaniem wodorków (HGAAS) oraz rtęci metodą „zimnych par” (CVAAS). Oceny narażenia na badane pierwiastki pobrane z owocami i produktami owocowymi dokonano biorąc pod uwagę średnie uzyskane poziomy zanieczyszczania oraz średnie spożycie tych grup środków spożywczych w Polsce.

Wyniki. Zanieczyszczenie badanych próbek $\mathrm{Pb}, \mathrm{Cd}$, As, $\mathrm{Hg}$ i Sn nie budzi obaw zdrowotnych i w większości przypadków było porównywalne z zanieczyszczeniem stwierdzanym w innych krajach europejskich. Oszacowane średnie narażenie

Corresponding author: Monika Mania, National Institute of Public Health NIH - National Research Institute, Department of Food Safety, 24 Chocimska str., 00-791 Warsaw, Poland, phone +48 225421 362, fax +48 225421 392, e-mail: mmania@pzh.gov.pl

(C) Copyright by the National Institute of Public Health NIH - National Research Institute 
dorosłych i dzieci związane z pobraniem ołowiu z owocami i produktami owocowymi wahało się od $0,5 \%$ do $14,6 \%$ najniższej dawki wyznaczającej - BMDL (Benchmark Dose Lower Confidence Limit) ustanowionej przez Europejski Urząd ds. Bezpieczeństwa Żywności (EFSA). Średnie pobranie kadmu z tymi grupami środków spożywczych wahało się od $0,3 \%$ do $8,5 \%$ tymczasowego tolerowanego tygodniowego spożycia - TWI (Tolerable Weekly Intake) ustalonego przez EFSA dla dorosłych i dzieci (0,1 - 3,6\% PTMI - tymczasowe tolerowane miesięczne pobranie) ustalonego przez JECFA. W przypadku arsenu średnie pobranie mieściło się w zakresie 0,5 -1,6\% BMDL, podczas gdy dla rtęci (forma nieorganiczna) stanowiło $0,5-1,4 \%$ wartości TWI.

Wnioski. Na podstawie uzyskanych wyników stwierdzono, że zawartość $\mathrm{Pb}, \mathrm{Cd}, \mathrm{As}, \mathrm{Hg}$ i $\mathrm{Sn}$ w badanych próbkach owoców i przetworów owocowych nie stanowi zagrożenia dla zdrowia konsumenta. Oszacowane narażenie konsumentów nie przekracza tolerowanych dawek ustalonych przez EFSA oraz JECFA dla tych pierwiastków.

Słowa kluczowe: żywność, owoce, monitoring, ołów, kadm, rtęć, arsen, cyna, ocena narażenia

\section{INTRODUCTION}

Fruits are an important component of the daily diet $[5,24]$. They are a source of vitamins (especially $\mathrm{C}, \mathrm{K}, \beta$-carotene, folates), minerals, fiber and natural antioxidants that remove free oxygen radicals harmful to the body $[1,12,13,26,28]$. A diet rich with, among others in fruit reduces the risk of cardiovascular diseases and cancer $[12,17]$. According to the data of the Polish Central Statistical Office (GUS), the average monthly fruit consumption in our country per capita is $3.86 \mathrm{~kg}$, including bananas and citrus fruits $1.51 \mathrm{~kg}$, berries $0.42 \mathrm{~kg}$ and apples $0.94 \mathrm{~kg}$ [11]. Contamination of environment may lead to accumulation of lead and cadmium in these foodstuffs, which are the source of heavy metals intake $[15,25,26,27]$. The presence of some metals in the fruit products, e.g. tin, may be related with the migration of this element from packaging such as cans due to surface damage. Despite the implementation of the principles of good manufacturing and agricultural practice in food production, it is not possible to completely eliminate the presence of chemical contaminants in food. It is also impossible to completely remove them from food, only a small part, e.g. present on the surface of fruits can be removed by careful washing and peeling [25, 27]. Metals accumulate in the body, and the effects of their toxic activity usually become visible after a number of months, years and even generations. These are primarily cardiovascular, kidney, nervous and skeletal diseases, abnormal development children, mutagenic and teratogenic changes, allergies, as well as neoplastic diseases.

Recent risk assessments performed by the European Food Safety Authority (EFSA) and the Joint FAO/ WHO Expert Committee on Food Additives (JECFA) contributed to the verification of previously accepted safe doses of tolerable intake of elements harmful to human health and they were mostly reduced.

In 2010 the Panel on Contaminants in the Food Chain (CONTAM) of the European Food Safety Authority identified lead for developmental neurotoxicity and cardiovascular effects in young children, and nephrotoxicity in adults as the critical effects for the risk assessment. The respective benchmark dose lower confidence limits (BMDLs) established by EFSA were as follows: for developmental neurotoxicity in young children $\mathrm{BMDL}_{01}, 0.50 \mu \mathrm{g} / \mathrm{kg}$ body weight (b.w.) per day, for effects on systolic blood pressure in adults $\mathrm{BMDL}_{01}, 1.50 \mu \mathrm{g} / \mathrm{kg}$ b.w. per day and for effects on prevalence of chronic kidney disease in adults $\mathrm{BMDL}_{10}, 0.63 \mu \mathrm{g} / \mathrm{kg}$ b.w. per day [4].

In case of cadmium, EFSA established a tolerable weekly intake (TWI) at $2.5 \mu \mathrm{g} / \mathrm{kg}$ b.w. [19, 20]. In 2010, JECFA considering the long half-life of cadmium, and taking into account the negligible effect of daily exposure on overall exposure, decided to express the tolerable intake for $\mathrm{Cd}$ as a monthly value of PTMI at $25 \mu \mathrm{g} / \mathrm{kg}$ b.w. [20]. For arsenic, the CONTAM panel of EFSA established BMDL ${ }_{01}$ values between $0.3 \mu \mathrm{g} /$ $\mathrm{kg}$ and $8 \mu \mathrm{g} / \mathrm{kg}$ b.w. per day for lung, skin, and bladder cancer, as well as skin lesions [18]. JECFA for arsenic computed $\mathrm{BMDL}_{0.5}$ at $3.0 \mu \mathrm{g} / \mathrm{kg}$ b.w. per day $(2.0 \mu \mathrm{g} /$ $\mathrm{kg}$ b.w. per day $-7.0 \mu \mathrm{g} / \mathrm{kg}$ b.w. per day) [14, 22].

In 2010, JECFA adopted PTWI for inorganic mercury at $4.0 \mu \mathrm{g} / \mathrm{kg}$ and for organic mercury at $1.6 \mu \mathrm{g} / \mathrm{kg}$ b.w. In the final opinion of 2012, EFSA established a TWI for methylmercury at $1.3 \mu \mathrm{g} / \mathrm{kg}$ b.w and confirmed TWI at $4.0 \mu \mathrm{g} / \mathrm{k}$ b.w. for inorganic mercury [21]. The maximum levels for certain heavy metals are set by Commission Regulation (EC) No 1881/2006 with late changes [3].

The monitoring studies provide information on the systematic assessment of contamination with heavy metals groups of products that contribute significantly to dietary intake, as well as relatively low consumption foodstuffs, but containing raw materials characterized by the accumulation of metals $[25,27]$. These studies are cyclical.

According to Regulation (EU) 2017/625 of the European Parliament and of the Council of 15 March 2017 in order to verify that the requirements of the legislation are compiled in Member States, official controls and monitoring of foodstuffs are carried out. The selection of foodstuffs monitored in subsequent years, in addition to the systematic assessment of contamination, is dictated by the verification and setting of subsequent limits for metal content in 
food legislation within the European Commission's Expert Committee on Environmental and Industrial Contaminants and the FAO/WHO Codex Alimentarius Commission [25, 26, 27].

The aim of the studies was the analysis of the results of monitoring undertaken in Poland in 2015 concerning contamination of lead $(\mathrm{Pb})$, cadmium $(\mathrm{Cd})$, arsenic (As), mercury $(\mathrm{Hg})$ and tin $(\mathrm{Sn})$ in fruit and fruit products and exposure assessment.

\section{MATERIALS AND METHODS}

The investigation carried out in 2015 included the determination of lead, cadmium, arsenic, mercury and tin (only for products in metal packaging) in fruit and their products. The research covered approximately 600 samples of fresh, frozen and dried fruits, fruit preserves and canned fruits. Samples were collected throughout the country by the Sanitary and Epidemiological Stations, based on a plan developed by the Food Safety Department of the National Institute of Public Health NIH - National Research Institute (NIH NIH-NRI), taking into account inter alia, population in the region and the share of domestic samples (taken from the market and producers respectively) and imports, which ensures that the results are representative. The samples were taken in accordance with the Commission Regulation (EC) No 333/2007 [2].

Laboratories of the State Sanitary Inspection participating in the studies used validated analytical methods that meet the criteria set out in the legislation for methods recommended in the official food control. As part of the internal confirmation of the validity of the test results, reference materials with certified metal content were used. Laboratories also checked their proficiency in this area by participating in interlaboratory tests. Laboratories of the State Sanitary Inspection participate in proficiency tests organized, among others by the Laboratory of the Food Safety Institute NIH NIH-NRI.

The contents of lead and cadmium in tested samples were determined by flame atomic absorption spectrometry (FAAS) method or flameless with electrothermal atomization spectrometry (GFAAS). Arsenic was determined using hydride generation atomic absorption spectrometry (HGAAS) method and mercury by "cold vapor" atomic absorption spectrometry (CVAAS) method. The test samples were prepared in accordance with the European Standard PN-EN 13804:2013 [6].

\section{Statistical assessment of the analytical results}

Statistical assessment of results was performed according the substitution method used by EFSA for the treatment of left-censored data - LC (below limit of detection, limit of quantification (LOD/LOQ)). For results reported to be below the $\mathrm{LOD} / \mathrm{LOQ}$, the value equal to the LOD/LOQ (upper bound - UB), zero (lower bound - LB) or half the LOD/LOQ (medium or middle bound - MB) was used [23]. Different numbers of results below LOD/LOQ were observed in the analyzed samples. Depending on element leftcensored data were between $100 \%$ for mercury in frozen fruits and 7\% for tin (Sn) in canned fruits.

Health exposure to the studied elements from fruits and fruit products was assessed taking into account the average contamination levels obtained and average domestic consumption of these food products in Poland.

\section{RESULTS AND DISCUSSION}

The investigation conducted in 2015 included around 269 samples of fresh fruits (including 165 samples of berries and other small ones, i.e. raspberries, strawberries, currants, blackberries, gooseberries, cranberries, blueberries and grapes and 104 samples of other fresh fruits), 52 samples of dried fruits, 59 samples of frozen fruits (including 39 berries and other small ones and 222 preserves (including 67 small fruit, 83 other fruits and 72 samples of canned fruits).

The lead content was determined in 530 samples of fruit and fruit products, cadmium in 603, arsenic in 554 , mercury in 559 and tin in 69.

The research covered products from domestic production and imported from European Union countries and from outside the EU, corresponding to the profile of products on the market in a given voivodship. According to the assumption, samples of domestic products constituted about $2 / 3(65 \%)$ of the examined samples, foodstuffs produced in other European Union countries - about $20 \%$, and the remaining - samples from outside the EU - about 15\%.

The results of the studies are given in the Figures 1-4. Parameters presented in the figures (values of mean, median and 90th percentile) concerning only middle bound (MB) approach.

\section{Lead}

Mean content of lead in in the group of berries and other small fresh fruits such as strawberries, raspberries, currants, blueberries and gooseberries, was in the range from lower bound (LB) to upper bound (UB): LB: $0.008 \div$ UB: $0.017 \mathrm{mg} / \mathrm{kg}$; P90 LB: $0.026 \div$ UB: $0.038 \mathrm{mg} / \mathrm{kg}$ ) (Figure 1).

The highest value of lead was detected in a sample of red grapes from Peru at $0.084 \mathrm{mg} / \mathrm{kg}$. Investigation carried out by other authors indicate higher contamination of small fruit such as strawberries and black currents, the mean contamination was as follows: $0.074 \mathrm{mg} / \mathrm{kg}$ and $0.074 \mathrm{mg} / \mathrm{kg}$ [13]. For 


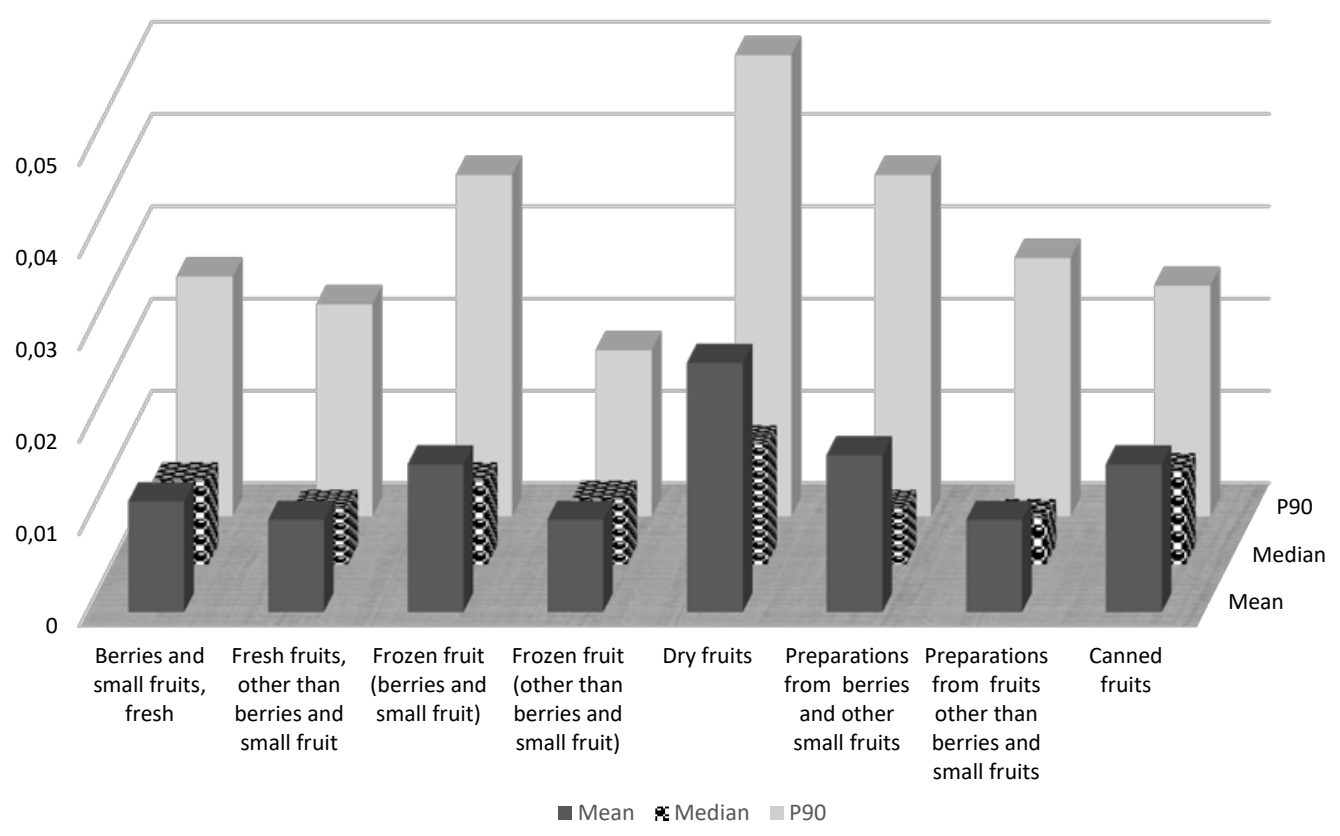

Figure 1. Lead content in fruit and their products, $\mathrm{mg} / \mathrm{kg}$

fresh fruit other than berries and small ones, mean contamination was in the range (LB-UB: $0.006-0.015$ $\mathrm{mg} / \mathrm{kg}$ ); P90: (LB-UB: $0.022-0.029 \mathrm{mg} / \mathrm{kg}$ ). There were no significant differences in the contamination of fruits from the domestic market compared to imported ones, including from other EU countries. The results of lead found in this group of fruits was lower than in the previous monitoring studies led in the years 2004-2008 [25, 26] and slightly lower in comparison to results collected by other Member States [14].

Average contamination of frozen fruits such as berries and other small fruits with lead was in the range: (LB-UB) $0.011-0.022 \mathrm{mg} / \mathrm{kg}$; (P90: 0.037 $0.003 \mathrm{mg} / \mathrm{kg}$ ) whilst for other frozen fruits: 0.004 - 0.015 mg/kg (P90: 0.018 - 0.026 mg/kg). Domestic fruits, especially berries and other small ones, were characterized by lower mean (MB) contamination than the imported ones (domestic: $0.015 \mathrm{mg} / \mathrm{kg}$; imported: $0.022 \mathrm{mg} / \mathrm{kg}$ ), whilst in case of other fruits there was no difference in contamination. Lead content in dried fruits was between LB: $0.021 \mathrm{mg} / \mathrm{kg}$ and UB: 0.034 $\mathrm{mg} / \mathrm{kg}$; P90: $0.042-0.099 \mathrm{mg} / \mathrm{kg}$ and was comparable to reported in other EU countries (mean LB-UB: 0.023 $-0.028 \mathrm{mg} / \mathrm{kg}$ ) [14]. The highest value was reported in a sample of dried raisins from Iran $-0.150 \mathrm{mg} / \mathrm{kg}$

The results survey of a total diet study undertaken by the Food Safety Authority of Ireland (FSAI) in 20122014 indicate lower lead contamination of dried fruits as compared with results obtained in Poland, mean was in the range (mean LB-UB): 0 - $0.02 \mathrm{mg} / \mathrm{kg}$ [8].

Products from domestic fruit, especially berries and other small ones, were characterized by higher lead contamination, average (MB) was $0.018 \mathrm{mg} / \mathrm{kg}$ compared to imported products, average: $0.008 \mathrm{mg} /$ $\mathrm{kg}$. For preserves from other fruits, the contamination of domestic fruits was lower - $0.009 \mathrm{mg} / \mathrm{kg}$ compared to imported products, including those from other EU countries - $0.017 \mathrm{mg} / \mathrm{kg}$ (mean MB) (e.g. Portugal, Germany, Denmark, Greece and from outside the EU: Thailand, China). Whereas, in the case of canned fruits, the mean (MB) contamination of domestic and imported products was comparable (country: 0.020 $\mathrm{mg} / \mathrm{kg}$; import $0.015 \mathrm{mg} / \mathrm{kg}$ ). Higher results in scope of contamination with lead were obtained in Ireland, mean was in the range (LB-UB): $0.02-0.11 \mathrm{mg} / \mathrm{kg}$ [8].

\section{Cadmium}

The mean cadmium content of the tested fresh berries and small fruits, imported from other countries, was slightly lower compared to domestic products (Figure 2).

The average content of cadmium in domestic products was in the range: $0.005-0.006 \mathrm{mg} / \mathrm{kg}$ (LBUB), while in imported products $0.000-0.001 \mathrm{mg} /$ $\mathrm{kg}$ (LB-UB). In case of fresh fruits domestic origin other than berries and small ones, even lower levels were observed: mean (LB-UB) was: $0.002-0.003 \mathrm{mg}$ / $\mathrm{kg}$. Only slightly higher contamination of berries and small fruits with cadmium was observed in other EU countries, mean: $0.003-0.005 \mathrm{mg} / \mathrm{kg}$ [20].

The survey conducted by the Food Standard Australia and New Zealand agency indicate slightly higher contamination of small fruits with cadmium, as compared with results obtained in Poland (mean was $0.015 \mathrm{mg} / \mathrm{kg}$ ) [7].

Cadmium contamination of tested samples of frozen small fruits was slightly higher than in case of other frozen fruits other than berries. The obtained mean contamination was in the range: $0.010-0.011 \mathrm{mg} / \mathrm{kg}$ (LB-UB). The average (LB-UB) cadmium content in 


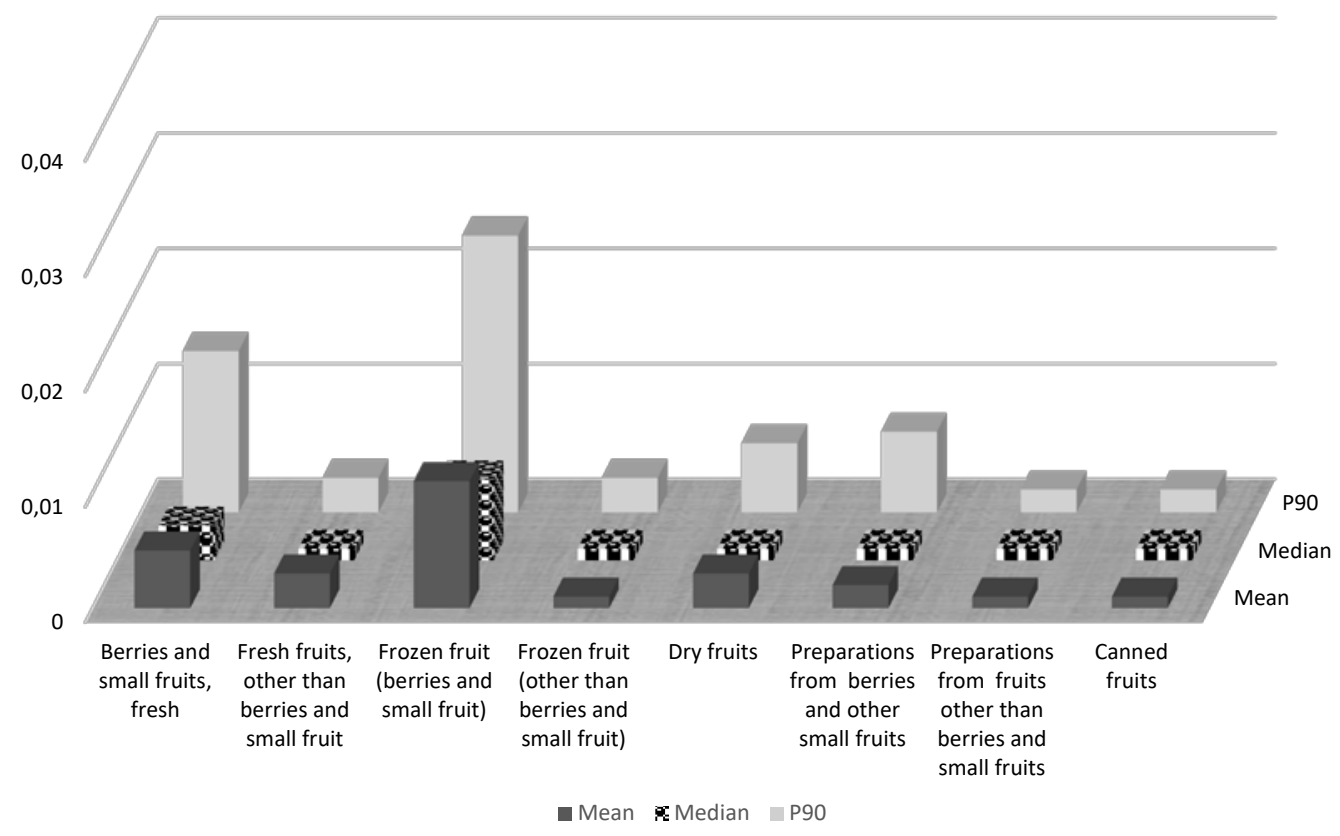

Figure 2. Cadmium content in fruit and their products, $\mathrm{mg} / \mathrm{kg}$

the preserves of berry fruits was: $0.002-0.003 \mathrm{mg} / \mathrm{kg}$ (P90: $0.007-0.007 \mathrm{mg} / \mathrm{kg}$ ) whilst in preserves from other fruits $0.001-0.002 \mathrm{mg} / \mathrm{kg}$ (P90: $0.001-0.003 \mathrm{mg}$ / $\mathrm{kg}$ ). Cadmium contamination of the tested domestic and imported products did not differ significantly.

Domestic dried fruits characterized slightly higher mean contamination with cadmium than imported dried fruits, mean was: $0.007-0.008 \mathrm{mg} / \mathrm{kg}$ (P90: $0.018 \mathrm{mg} / \mathrm{kg}$ ) and $0.0014-0.004 \mathrm{mg} / \mathrm{kg}$ P90 (LB: 0.000 $\div$ UB: $0.003 \mathrm{mg} / \mathrm{kg}$ ) respectively. Contamination with cadmium of the tested imported dried fruits was lower than observed in other European countries, mean was in the range: $0.0022-0.0072 \mathrm{mg} / \mathrm{kg}$ [20]. Content of cadmium in canned products regardless of origin was low, mean was: $0.0003-0.002 \mathrm{mg} / \mathrm{kg}$; P90 (LBUB: $0.000-0.003 \mathrm{mg} / \mathrm{kg}$ ). Similar low results were obtained in Ireland [8].

\section{Arsenic}

Contamination with arsenic was low and does not pose a health concern. The mean (LB-UB) content of arsenic in the tested samples was between $0.001 \mathrm{mg} /$ $\mathrm{kg}$ in preparations from berries and other small fruits, including canned fruits to $0.021 \mathrm{mg} / \mathrm{kg}$ in frozen berries and other small fruits, (90th percentile 0 $0.050 \mathrm{mg} / \mathrm{kg}$ ) (Figure 3).

Contamination of domestic fresh berries and small fruits was comparable to the imported products and similar to other fresh fruits. In case of dried fruits domestic origin, lower contamination with arsenic was observed in comparison to imported dried fruits, mean was in the range: $0-0.016 \mathrm{mg} / \mathrm{kg}$ and 0.007 $0.021 \mathrm{mg} / \mathrm{kg}$ (LB-UB) accordingly; (90th percentile (LB-UB) was: $0-0.026 \mathrm{mg} / \mathrm{kg}$ ) whilst for imported product $0.023-0.032 \mathrm{mg} / \mathrm{kg}$. Contamination of berries and other small fruits as well as dried fruits with arsenic reported in Poland was comparable to observed in other EU countries whilst other fruits was significantly lower [19]. The highest values of arsenic were in the samples of frozen domestic strawberries at $0.123 \mathrm{mg} / \mathrm{kg}$ and fresh kiwi from Spain at $0.09 \mathrm{mg} / \mathrm{kg}$.

\section{Mercury}

The reported mean mercury contents in tested samples were low and did not pose a health risk. The mean contents (LB-UB) of mercury in the groups of fresh fruits such as berries and other small fruits as well as other fruits were as follows: $0.0004-0.0021 \mathrm{mg} /$ $\mathrm{kg}$ (90th percentile $0.001-0.005 \mathrm{mg} / \mathrm{kg}$ ) and $0.0003-$ $0.0017 \mathrm{mg} / \mathrm{kg}$ (90th percentile $(0.0001-0.004 \mathrm{mg} / \mathrm{kg}$ ). Similar low results were obtained for frozen fruits, fruits preparations and canned products. Slightly higher level of mercury was detected in dry fruits mean (LB-UB) was in the range: $0.0009-0.003 \mathrm{mg} / \mathrm{kg}$ (90th percentile: $0.002-0.005 \mathrm{mg} / \mathrm{kg}$ ). Contamination of mercury domestic and imported fruits and their products was comparable (Figure 4). The highest value of mercury was found in the imported dried apples at $0.016 \mathrm{mg} / \mathrm{kg}$. Obtained results in scope of mercury contamination were comparable with results collected by EFSA from other EU countries [21]. Investigation carried out in UK within Total Diet Study showed significantly lower contamination of fresh fruits and fruit product with mercury [16]. The results of the conducted studies indicate a comparable mercury and cadmium contamination, lower with lead and arsenic in comparison to the monitoring studies carried out in the years 2004-2008 [25, 27]. 


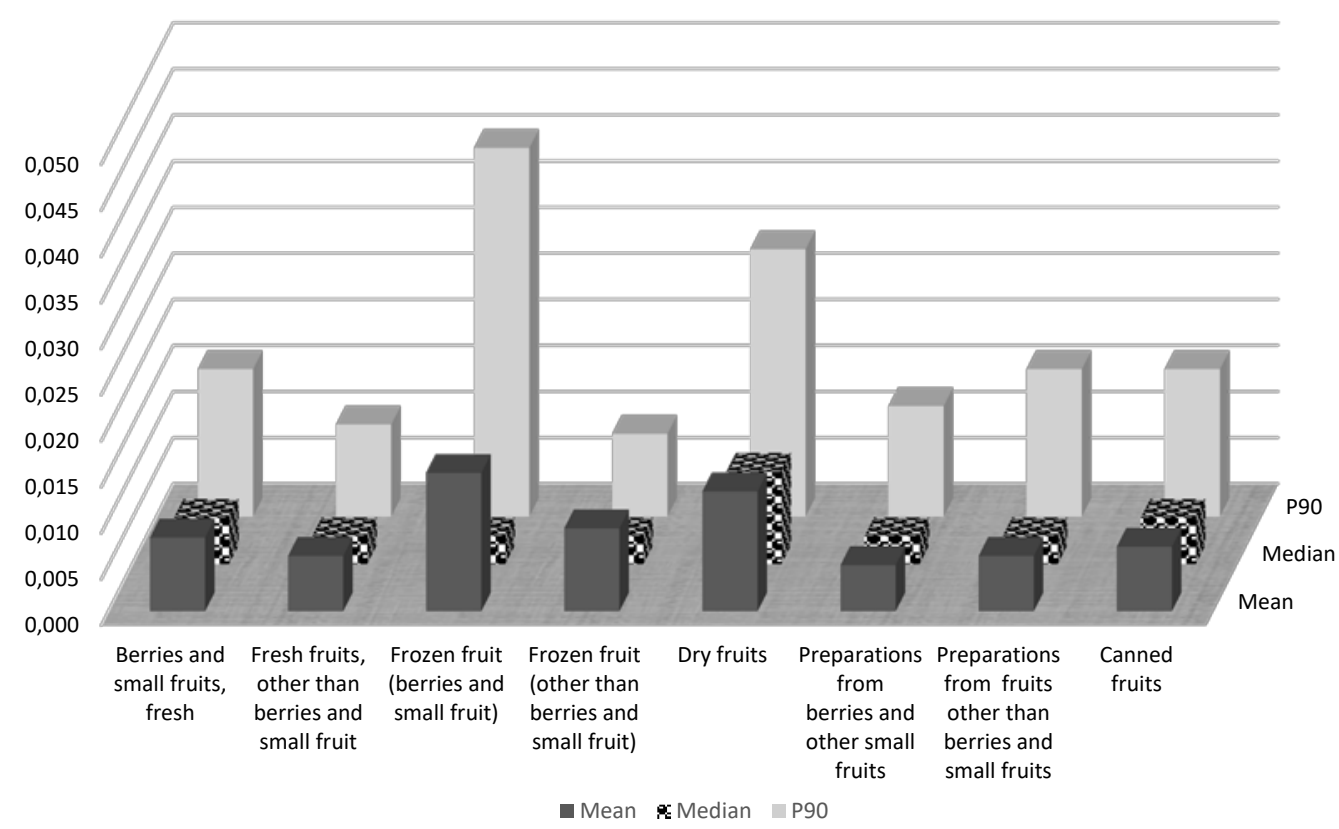

Figure 3. Arsenic content in fruit and their products, $\mathrm{mg} / \mathrm{kg}$

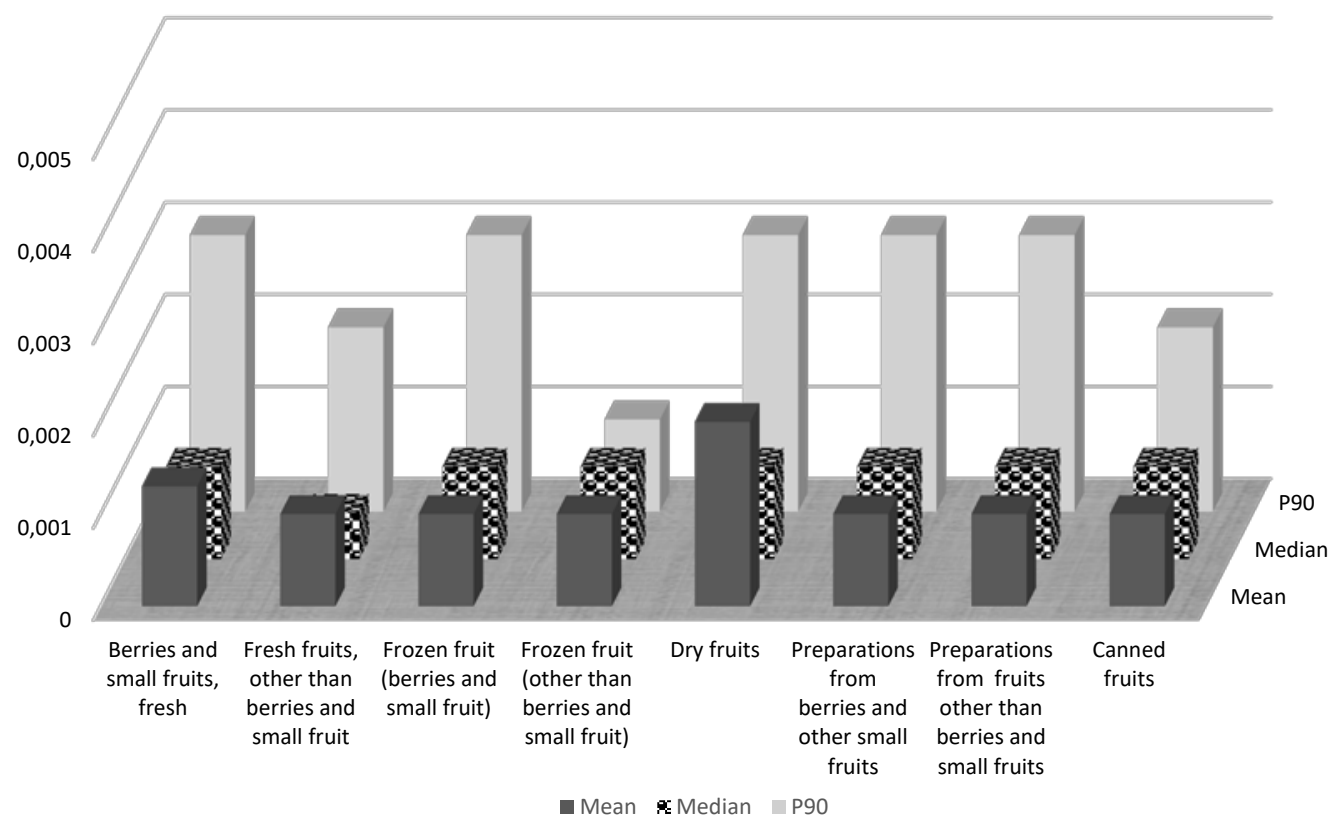

Figure 4. Mercury content in fruit and their products, $\mathrm{mg} / \mathrm{kg}$

Tin

Contamination with tin of tested fruit samples and their products does not pose a health risk. The mean (LB-UB) content was in the range: $69.7-70.1 \mathrm{mg} /$ $\mathrm{kg}$ (90th percentile LB-UB: $140-140 \mathrm{mg} / \mathrm{kg}$ ), the highest value was registered in the sample of pears in syrup from China - $206 \mathrm{mg} / \mathrm{kg}$, the lowest value in a sample of sliced tomatoes of domestic origin $2.39 \mathrm{mg} / \mathrm{kg}$. In Total Diet Study conducted in UK the highest concentration of tin was measured in the canned or jarred vegetables $(30.1 \mathrm{mg} / \mathrm{kg})$ with lower levels detected in the fruit products $(6.16 \mathrm{mg} / \mathrm{kg})$ [9]. The main reason of significant migration of tin is poor quality of packaging and it is mainly the case of imported products.

\section{Estimation of intake of toxic elements}

Assessment of risk to human health was performed taking into account current reference doses for elements introduced by EFSA and JECFA. To assess the dietary exposure to noxious elements $(\mathrm{Pb}, \mathrm{Cd}, \mathrm{As}, \mathrm{Hg})$ from commercially available fruits and their products mean and high contamination levels (90th percentile), middle bound values were taken into account.

The calculated intake is based on the Central Office of Statistics data on the consumption of these groups food products in Poland [11]. 
Taking into account the highest mean of medium bound (MB) value for lead present in the group of fresh fruits (berries, small fruits and other fruits), the calculated mean intake of lead with fresh fruits on MB values of contamination would constitute $3.3 \%$ of the BMDL $_{10}$ dose (nephrotoxicity effects - adults) and 1.4\% of the dose $\mathrm{BMDL}_{01}$ (cardiovascular disorders - adults). It should be emphasized that in the case of children by several fold lower body weight, lead uptake expressed as $\%$ BMDL value would be much higher. For mean (MB) value of contamination intake would be $14.6 \%$ of BMDL ${ }_{01}$ value. At the level of 90th percentile (MB) intake of lead with fresh fruits would be: $7.13 \%, 2.9 \%$ and $31.5 \%$ BMDL value respectively.

Mean intake of lead with fruits preparations would be below $0.5 \%$ of BDML value for cardiovascular and nephrotoxicity effects for adults, whilst for children constituted $1.3-2.1 \% \mathrm{BMDL}_{01}$. Calculated intake of lead at 90th percentile of contamination was in the range from $0.12 \%$ for adults (cardiovascular disorders) to $1.3 \%$ of $\mathrm{BMDL}_{01}$ value (the effect neurotoxicity in young children). Estimated dietary exposure based on (MB) mean and 90th percentile lead occurrence was lower than assessed in France in the scope of fruit products, whilst slightly higher for fresh fruits [10].

Mean intake of cadmium from the fresh fruits, ranges from $2.4 \%$ of the TWI established by EFSA for adults to $8.5 \%$ TWI for children, which represents $1.04-3.6 \%$ of the PTMI value established by JECFA. Cadmium exposure based on 90th percentile (MB) assumption of contamination would be in the range: $6.8 \%$ TWI for adults to $23.7 \%$ TWI for children. It represents from $2.9 \%$ to $10.2 \%$ PTMI established by JECFA. Mean intake of cadmium with different fruit products was low and constituted from $0.3 \%$ for adults to $1.2 \%$ TWI for children (0.1 - 0.5\% PTMI). Exposure at 90 th percentile $(\mathrm{MB})$ assumption of contamination in case of fruit products ranges from $0.7 \%$ TWI value for adults to $2.5 \%$ TWI for children (0.3-1.1\% PTMI). Estimated exposure to cadmium was lower than in France for fruit products and only slightly higher for fresh fruits [10].

Intake of arsenic with fresh fruits does not exceed tolerable doses (approx. $0.5 \%$ of $\mathrm{BMDL}_{0.5}$ value for adults and $1.6 \%$ for children. Arsenic exposure based on 90th percentile MB assumption constituted 0.9 $3.2 \%$ BMDL value respectively. Intake of arsenic with fruits products was even lower and does not exceeded $0.5 \%$ of BDML value for both children and adults (90th percentile of exposure: $0.2-0.5 \%$ of BMDL for both effects).

Estimated exposure to mercury, assuming that total mercury is represented only by its inorganic compounds does not exceed tolerable dose $(4.0 \mu \mathrm{g} / \mathrm{kg}$ b.w. per week).
Based on mean (MB) concentration of mercury in fresh fruits, the dietary exposure to inorganic mercury from the investigated products corresponds from $0.5 \%$ of TWI for adults to $1.4 \%$ TWI for children. Taking into account 90th percentile (MB) assumption intake of mercury (as inorganic) would be in the range 1.1 - 3.2\% respectively. Calculated mean (MB) intake of inorganic mercury with fruit products as well as intake at 90th percentile of contamination level was below $0.5 \%$ of TWI for adults and children and did not pose a health hazard.

\section{CONCLUSIONS}

1. The contents of lead, cadmium, arsenic, mercury and tin found in the tested foodstuffs were low and did not pose a risk to consumer health.

2. There were no significant differences in contamination of domestic products and products from other European Union countries

3. Estimated consumer exposure does not exceed the tolerable doses established by EFSA and JECFA for these elements.

4. The monitoring studies of fruit and their products in this scope will be continued.

\section{Conflict of interest}

The authors declare no conflict of interest.

\section{Acknowledgements}

The authors would like to thank the staff of the Sanitary Epidemiological Stations for their assistance and cooperation in this monitoring program.

\section{REFERENCES}

1. Anastácio M., A.P. Marreilha dos Santos A.P., Aschner M., Mateus L.: Determiantion of trace metals in fruit juices in the Portuguese market. Toxicol Reports, 2018;(5):434-439.

2. Commission Regulation (EC) No 333/2007 of 28 March 2007 laying down the methods of sampling and analysis for the official control of the levels of lead, cadmium, mercury, inorganic tin, 3-MCPD and benzo(a)pyrene in foodstuffs. OJ EU L 88 of 28 March 2007, as amended

3. Commission Regulation (EC) No 1881/2006 of 19 December 2006 setting maximum levels for certain contaminants in foodstuffs. OJ EU L 364 of 20 December 2006, as amended

4. EFSA Panel on Contaminants in the Food Chain (CONTAM). Scientific Opinion on Lead in Food. EFSA J. 2010;8(4):1570.

5. Elbagermi M.A., Edwards H.G.M., Alajtal A.I.: Monitoring of Heavy Metal Content in Fruits and Vegetables Collected from Production and Market Sites in the Misurata Area of Libya. International Scholarly Research Network ISRN Analytical 
Chemistry 2012, Article ID 827645, 5 pages, https://doi. org $/ 10.5402 / 2012 / 827645$.

6. European Standard. PN-EN 13804:2013. Foodstuffs Determination of elements and their chemical species - General considerations and specific requirements.

7. Food Standards Australia and New Zealand (FSANZ). 25nd Australian Total Diet Study. 2019

8. Food Safety Authority of Ireland. Report on a Total Diet Study carried out by the Food Safety Authority of Ireland in the period $2012-2014$. Food Safety Authority of Ireland, FSAI 2016;1-133; ISBN 978-1-910348-06-2

9. Food Standards Agency. Measurement of the concentrations of metals and other elements from the 2014 UK Total Diet Study.

10. French Agency for Food, Environmental and Occupational Health \& Safety. Second French Total Diet Study (TDS 2) Report 1. Inorganic contaminants, minerals, persistent organic pollutants, mycotoxins and phytoestrogens. ANSES, 2011, 1-304. Available at: https://www.anses.fr/en/system/files/ PASER2006sa0361Ra1EN.pdf

11. GUS. Central Office of Statistics Database, Household budget survey in 2020. Warsaw 2021.

12. Jarosz M., Rychlik E., Stoś K., Charzewska J.: Normy żywienia dla populacji Polski i ich zastosowanie. Narodowy Instytut Zdrowia Publicznego - Państwowy Zakład Higieny. 2020; ISBN: 978-83-65870-28-5

13. Krejpcio Z., Sionkowski S., Bartela J.: Safety of fresh fruits and juices available on the Polish market as determined by heavy metal residues. Pol. J. Environ. Stud. 2005;14(6): 877-881.

14. Lead dietary exposure in the European population. EFSA Journal 2012;10(7):2831.

15. Melai V., Giovannini A., Chiumiento F., Bellocci M., Migliorati G.: Occurrence of metals in vegetables and fruits from areas near landfill in Southern Italy and implications for human exposure. Int. J. Food Contam. 2018;5:8. https://doi.org/10.1186/s40550-018-0070-5

16. Rose M., Baxter M., Brereton N., Baskaran Ch.: Dietary exposure to metals and other elements in the 2006 UK Total Diet Study and some trends over the last 30 years. Food Addit Contam. 2010;27(10):1380.

17. Sajib M.A.M., Hoque M.M., Yeasmin S., Khatun M.H.A.: Minerals and heavy metals concentration in selected tropical fruits of Bangladesh. Int. Food Res. J. 2014;21(5): 1731-1736.

18. Scientific opinion of the Panel on Contaminants in the Food Chain (CONTAM) on arsenic in food. The EFSA J. 2009;7(10):1-199.

19. Scientific Opinion of the Panel on Contaminants in the Food Chain on a request from the European Commission on cadmium in food. The EFSA J. 2009;980: 1-139

20. Scientific Opinion of EFSA. Cadmium dietary exposure in the European population. The EFSA Journal 2012;10(1):2551.
21. Scientific Opinion on the risk for public health related to the presence of mercury and methylmercury in food. EFSA Panel on Contaminants in the Food Chain. The EFSA J. 2012;10(12):2985.

22. Scientific Report. Chronic dietary exposure to inorganic arsenic. The EFSA J. 2021;19(1):6380.

23. Scientific Report of EFSA. Management of leftcensored data in dietary exposure assessment of chemical substances. The EFSA J. 2010;8(3):1557:1-96.

24. Shambel G. Yami, Bhagwan Singh Chandravanshi, Taddese Wondimu, Cherinet Abuye.: Assessment of selected nutrients and toxic metals in fruits, soils and irrigation waters of Awara Melka and Nura Era farms, Ethiopia. SpringerPlus 2016;5:747, DOI 10.1186/s40064016-2382-3.

25. Starska K., Wojciechowska-Mazurek M., Mania M., Rebeniak M., Karłowski K.: Zanieczyszczenie żywności ołowiem i arsenem. [Contamination of food with lead and arsenic]. In: Karłowski K., Rybińska K., Postupolski J. (eds.): Ocena narażenia konsumentów na chemiczne i mikrobiologiczne zanieczyszczenia żywności programy realizowane w latach 2004-2008. [Exposure assessment to chemical and microbiological food contaminants - programme executed in the years 20042008].: National Institute of Public Health-National Institute of Hygiene, Warsaw, 2010, pp. 44-70 (in Polish).

26. Wojciechowska-Mazurek M., Starska K., Mania M., Brulińska-Ostrowska E., Biernat U., Karlowski $K$.: Monitoring of contamination of foodstuffs with elements noxious to human health. Part II. Mineral waters, soft drinks, fruits, nuts, rice, soybeans, fish and seafood. Rocz Panstw Zakl Hig 2010;61(1):27-35.

27. Wojciechowska-Mazurek, Starska, K., M., Mania, M., Rebeniak, M., Kartowski, K.: Zanieczyszczenie żywności kadmem i rtęcią. [Contamination of food with cadmium and mercury]. In: Kartowski K., Rybińska K., Postupolski J. (eds.): Ocena narażenia konsumentów na chemiczne i mikrobiologiczne zanieczyszczenia żywności - programy realizowane w latach 2004-2008. [Exposure assessment to chemical and microbiological food contaminants - programme executed in the years 2004-2008]. National Institute of Public Health-National Institute of Hygiene, Warsaw, 2010, pp. 13-40 (in Polish).

28. Yami S.G., Chandravanshi B.S., Taddese Wondimul T., Abuye Ch:: Assessment of selected nutrients and toxic metals in fruits, soils and irrigation waters of Awara Melka and Nura Era farms, Ethiopia. Springerplus 2016;5(1):747. doi: 10.1186/s40064-016-2382-3

Received: 05.11.2021

Accepted: 25.11.2021

Published online first: 30.11.2021 